\title{
EDITORIAL
}

\section{Transitions and Departures}

\author{
MATTHEW P. ROMANIELLO
}

W

ith the arrival of volume 19, our readers will notice there have been some changes to the editorial organization of Sibirica. This special issue on "Asia in the Russian Imagination," of which I am one of the guest editors, will be my final contribution to Sibirica. Last year I was presented the opportunity to become the editor of The Journal of World History for the next five years, which is a full-time obligation. I am excited to let you know that I have been succeeded as editor by Jenanne Ferguson. Professor Ferguson has a decade of experience working for the journal, in addition to her research contributions to the field, including her recent monograph, Words Like Birds: Sakha Language Discourses and Practices in the City (2019). I know that you all join me in wishing Professor Ferguson and her editorial team success as they steer the journal into the future.

The editorial change is not our only important transition with volume 19. Sibirica: Interdisciplinary Journal of Siberian Studies is now an Open Access publication, as part of Berghahn Books' Open Anthro Initiative, launched in partnerships with Libraria. This will extend the reach of Sibirica's scholarship and will make the journal a more prestigious venue for research on the region. Making the scholarship of our colleagues from Russia accessible to the Western readers has always been a significant accomplishment for the editors of Sibirica, and now we will all benefit from the publisher's commitment to making this material as widely accessible as possible.

With the enthusiasm and energy of a new editor combined with the broad reach of the journal's scholarship, there is no doubt that Sibirica has a bright future ahead. 